\title{
Predictors of the COVID-19 Social Distancing Practice among Undergraduate Health Students in Samarinda City, Indonesia: A Cross-Sectional Study
}

\author{
Siti Hadijah Aspan, Pramon Viwattanakulvanid*
}

College of Public Health Sciences, Chulalongkorn University, Bangkok, Thailand

\begin{abstract}
Social distancing is a health protocol recommended by the World Health Organization (WHO) for reducing the spread of COVID-19. Undergraduate health students play an important role in the dissemination of accurate information. This study identified predictors that influenced the COVID-19 social distancing practice and examined the sources of social distancing information among undergraduate health students in Samarinda City, Indonesia. This cross-sectional online survey study (March-April 2021) involved 422 undergraduate students from medicine, public health, and pharmacy faculties at Mulawarman University. Binary logistic regression was conducted to identify factors associated with the COVID-19 social distancing practice. The results showed that age (AOR = $1.47 ; 95 \% \mathrm{Cl}=1.97-2.22$, $\mathrm{p}$-value $=0.045)$, $\operatorname{sex}(\mathrm{AOR}=2.26 ; 95 \% \mathrm{Cl}=1.38-3.69$, $\mathrm{p}$-value $=0.001)$, and attitude $(\mathrm{AOR}=2.61 ; 95 \% \mathrm{Cl}=1.75-3.90 ; \mathrm{p}$-value $<0.001$ ) was significantly associated with social distancing practices. The top three sources of COVID-19 social distancing information used were social media $(80.6 \%)$, websites $(14.0 \%)$, and television (3.8\%). The study findings encourage the government to disseminate more health information on social media and education programs to this target population.
\end{abstract}

Keywords: COVID-19, social distancing practice, undergraduate health student

\section{Introduction}

Currently, coronavirus disease 2019 (COVID-19) has infected 235 million people all over the world. ${ }^{1}$ The community has consistently tracked new variants, and violations of health guidelines have hampered the government and related health authority efforts in controlling the spread of the COVID-19.2 The World Health Organization (WHO) recommends that citizens practice social distancing. ${ }^{3,4}$ Social distancing calls for maintaining a distance of at least one meter from the next person and avoiding groups and crowded places. ${ }^{1}$ Citizens worldwide have been urgently encouraged to implement social distancing in controlling the COVID-19 transmission. ${ }^{5-8}$ Nevertheless, the protocols have faced several problems during their implementation. ${ }^{3-9}$ Violation of social distancing has contributed to the massive increase in COVID-19 case numbers worldwide. Asymptomatic active carriers have been primarily found in already positive cases of COVID-19. ${ }^{9}$ Health guidelines such as social distancing are still supposed to be implemented correctly, even when people have received the second shot of the COVID-19 vaccine. Vaccines only minimize the symptoms of the illness, not completely counteract the

Correspondence ${ }^{*}$ : Pramon Viwattanakulvanid, Ph.D., College of Public Health Sciences, Chulalongkorn University, Institute Building 3 (10th-11th floor), Chulalongkorn soi 62, Phyathai Rd., Bangkok 10330, Thailand, E-mail: Pramon.V@chula.ac.th,Phone: 02-218-8337 virus. Therefore, compliance with social distancing will still be needed during the "new normal" era. ${ }^{10,11}$

General characteristics may impact the practice of social distancing; indeed, several studies have supported this assumption. ${ }^{12-17}$ Previous analytical studies have found that age and sex were associated with prevention practices of the COVID-19.12,13 A cross-sectional study conducted in Jakarta, Indonesia, indicated that undergraduate female students tended to apply good physical distancing behavior 3.4 times more than male students. ${ }^{14}$ Another cross-sectional study also revealed an association between gender and practice toward COVID-19 among medical students in India. ${ }^{15}$ The results of a study examining university students in the United Kingdom determined that gender and social distancing behavior were associated. ${ }^{16}$ Household income has likewise been found to influence the COVID-19 practices in Bangladesh. ${ }^{17} \mathrm{~A}$ study examining the COVID-19 social distancing policy in Jakarta, Indonesia, concluded that those with good levels of knowledge would show positive attitudes and practice social distancing compared with those who do not. $^{3}$

Health students are considered future leaders of

Received : June 08, 2021

Accepted : October 09, 2021

Published: November 29, 2021 
health promotion. This population tends to avoid health risk behavior and is more likely to endorse the benefits of positive behaviors. ${ }^{18}$ Health students are exposed to accurate information related to health rather than nonhealth students due to a lack of health risk awareness. ${ }^{19,20}$ However, studies regarding social distancing and factors influencing it among Indonesian undergraduate students are still inadequate, especially students in the health domain. The previous studies did not yet focus on undergraduate students that were predominantly filled with young people. This matter was considered a study limitation, suggesting that further research was required. ${ }^{15,21}$ These predictors and their effects on social distancing practice among undergraduate health students have not been investigated in Indonesian. For these reasons, the authors aimed to examine the predictors of social distancing practice and the sources of social distancing information that students often use. Thus, the study findings are beneficial for management, program evaluation, and promotion of social distancing in controlling the COVID-19 transmission.

\section{Method}

This study was designed as an online-based, crosssectional survey study. Undergraduate health students at Mulawarman University, Samarinda City, Indonesia was the target population. The online questionnaires were distributed through research assistants at each health faculty, including (1) Faculty of Medicine, (2) Faculty of Public Health, and (3) Faculty of Pharmacy. Participants were asked to read information sheets and consent forms before answering the online questionnaire through the Google Form link and followed up every three days until the end of the data collection period.

The participants were recruited using convenience sampling that met the eligibility. The minimum sample size was 418 subjects calculated using an infinite population formula with the proportion of practicing social distancing $=0.55 .{ }^{15}$ The data was collected from March to April 2021. Undergraduate medical students aged 18 years and above willingly signed informed consents. They were currently enrolled in the Faculty of Medicine, Faculty of Public Health, and Faculty of Pharmacy and were included in the study. Participants who do not own smartphones, have no access to the internet, and are unable to fill the questionnaire were excluded.

This study used an online, self-administered questionnaire adapted from a previous related study. 10,21-24 There were five sections in the questionnaire, including a general characteristic section represented by six items, knowledge related to social distancing by 24 items, attitude toward social distancing section by 16 items, the practice of social distancing by nine items, and a section of reasons for not practicing social distancing in one item.
The validity of questionnaires was tested using the ItemObjective Congruence Index method with three experts. The reliability of questionnaires regarding attitude and knowledge was tested with Cronbach's alpha coefficients and Kudar-Richardson Formula 20, respectively. Cronbach's alpha coefficient of attitude was 0.73 , and the knowledge scale was 0.65 . Finally, questionnaires were translated in Bahasa Indonesia with a back-translation method.

The current study examined the practice of social distancing among undergraduate health students as a dependent variable. It included keeping a distance of at least one meter from other people, avoiding crowded places and groups, and staying at home. The independent variables were chosen by a literature review from previous studies.3,21-24 The independent variables included knowledge, attitude, age, type of faculty, sex, length of time spent in the university, and family income. The details of the variables are shown in the results tables. Variable knowledge was measured by calculating the median score, as data is non-normally distributed indicated by Shapiro Wilks test was under p-value (0.05), therefore this variable categorized as good knowledge (if participants score more or equal than median) or poor knowledge (if participants score less than median). The attitude was measured with a five-point Likert scale. All answers were computed to obtain total scores; then, median scores resulting from non-normally distributed data were calculated to categorize as positive or negative attitudes. For practice, it was measured by a 3-point Likert scale. All answers to practice questions were computed to obtain median scores due to non-normally distribution and categorized as good practice (if participants score more or equal than median) or poor practice (if participants score less than median). The results of the source of information are shown in the charts.

Bivariate and multivariable analyses of the data were performed for this study. The data distribution was checked with scatter plots and a Shapiro. Categorical data were calculated as frequencies and percentages. Bivariate analysis with Chi-square test was initially performed to screen the significant factors with significance level $p$-value $<0.25$. Next, significant factors were included in the binary logistic regression model. Finally, multivariable analysis using binary logistic regression was conducted to identify the final important factors associated with dependent variables, with the calculation of adjusted odds ratio (AOR) and p-value $<0.05$ considered statistically significant. The data were analyzed using the SPSS version 22 software (SPSS Inc., Chicago IL).

\section{Results}

Four hundred and twenty-two participants were involved in this study. The average age was 21 years old 
(range 18-25 years), and the standard deviation was 1.76. Approximately $50.5 \%$ were in the range of age 18 21 years old. Some $45 \%$ came from the Faculty of Pharmacy, $76.8 \%$ were female students, and $71.8 \%$ studied at the university for three years or above. In addition, $53.3 \%$ came from families with household incomes of $\leq 3,100,000$ IDR per month (Table 1). As shown in Figure 1, the sources of information used by participants were social media $(80.6 \%)$, followed by official websites provided by the WHO/Indonesia COVID19 taskforce $(14.0 \%)$, television $(3.8 \%)$, and by-mouth from friends/family/relatives/lecturers $(1.7 \%)$.

The bivariate analysis results in Table 2 showed the significant association of two variables from general characteristics toward social distancing practice. Those were age $(\mathrm{p}$-value $=0.040)$ and sex $(\mathrm{p}$-value $=0.001)$. Attitude level toward social distancing was also significantly associated statistically with social distancing practice with a p-value of $<0.001$. Nevertheless, the knowledge variable was still input into the binary logistic regression model as it was considered an important predictor due to Knowledge-Attitude-Practice theory.

The findings of binary logistic regression indicated that age, sex, and attitude were significant predictors of the COVID-19 social distancing practice. Older students aged 21-25 years were 1.47 times more likely to have good social distancing than students from 18-21 years (AOR $=1.47 ; 95 \% \mathrm{CI}=1.97-2.22)$. Female students were 2.26 times more likely to have good practice in social distancing than males ( $\mathrm{AOR}=2.26 ; 95 \% \mathrm{CI}=1.38$ 3.69). Health students with positive attitudes toward social distancing practice were 2.61 times more likely to have good practice in social distancing than health students with negative attitude $(\mathrm{AOR}=2.61 ; 95 \% \mathrm{CI}=$ 1.74-3.90). However, there was still no significant association between knowledge and social distancing practice (Table 3).

Table 1. General Characteristic of Participants $(n=422)$

\begin{tabular}{|c|c|c|c|}
\hline Characteristic & Category & $\mathbf{n}$ & $\%$ \\
\hline \multirow[t]{2}{*}{ Age $($ Mean \pm SD: $21 \pm 1.76)$} & 18-21 years old & 214 & 50.5 \\
\hline & $22-25$ years old & 208 & 49.3 \\
\hline \multirow{3}{*}{ Faculty } & Medicine & 121 & 28.7 \\
\hline & Public health & 111 & 26.3 \\
\hline & Pharmacy & 190 & 45.0 \\
\hline \multirow[t]{2}{*}{ Sex } & Male & 98 & 23.2 \\
\hline & Female & 324 & 76.8 \\
\hline \multirow[t]{2}{*}{ Length of study spent in the university } & $<3$ years & 119 & 28.2 \\
\hline & $\geq 3$ years & 303 & 71.8 \\
\hline \multirow[t]{2}{*}{ Family income } & $<3.100 .000$ IDR & 197 & 46.7 \\
\hline & $\geq 3.100 .000 \mathrm{IDR}$ & 225 & 53.3 \\
\hline
\end{tabular}

Notes: SD = Standard Deviation; IDR = Indonesian Rupiah

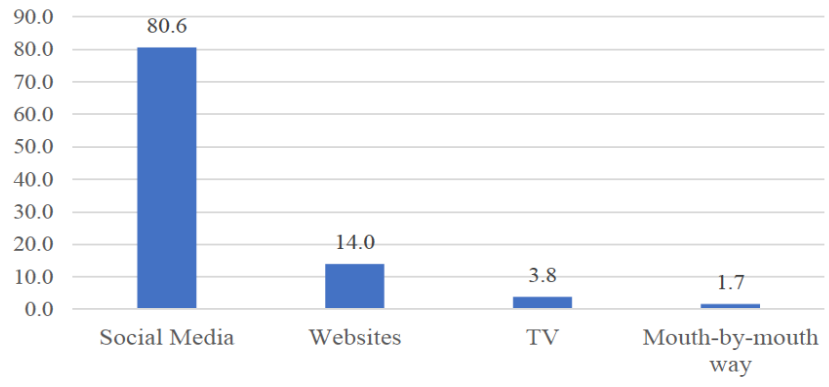

Figure 1. Sources of Information related to Social Distancing

Table 2. Bivariate Analysis of Association between General Characteristics, Knowledge, and Attitude toward Practice of Social Distancing $(n=422)$

\begin{tabular}{|c|c|c|c|c|c|c|}
\hline \multirow[b]{2}{*}{ Variable } & \multirow[b]{2}{*}{ Category } & \multicolumn{2}{|c|}{ The Practice of Social Distancing } & \multirow[b]{2}{*}{ COR } & \multirow[b]{2}{*}{$95 \%$ CI } & \multirow[b]{2}{*}{ p-value } \\
\hline & & Poor & Good & & & \\
\hline Age (years) & $18-21$ & $107(52.7)$ & $107(48.6)$ & 1 & & $0.040^{*}$ \\
\hline Sex & Female & $141(69.8)$ & $183(83.2)$ & 2.14 & $1.34-3.40$ & \\
\hline \multirow[t]{3}{*}{ Faculty } & Medicine & $54(26.7)$ & $67(30.5)$ & 1 & & \\
\hline & Public Health & $49(24.3)$ & $62(28.2)$ & 1.02 & $0.60-1.17$ & 0.288 \\
\hline & Pharmacy & $99(49.0)$ & $91(41.4)$ & 0.74 & $0.46-1.17$ & \\
\hline \multirow[t]{2}{*}{ Spent time in the university } & $<3$ years & $53(26.2)$ & $66(30.0)$ & 1 & & 0.391 \\
\hline & $\geq 3$ years & $149(73.8)$ & $154(70.0)$ & 0.83 & $0.54-1.27$ & \\
\hline $\begin{array}{l}\text { Knowledge regarding social } \\
\text { distancing }\end{array}$ & Good & $134(66.3)$ & $143(65.0)$ & 0.94 & $0.63-1.40$ & \\
\hline \multirow[t]{2}{*}{ Attitudes toward social distancing } & Negative & 119 (58.95) & $78(35.0)$ & 1 & & $<0.001^{*}$ \\
\hline & Positive & $83(41.1)$ & $142(64.5)$ & 2.61 & $1.76-3.86$ & \\
\hline
\end{tabular}

Notes: aBivariate analysis (Chi-square test), *Selection of significant factors at $\mathrm{p}$-value $<0.25, \mathrm{CI}=$ Confidence Interval, IDR $=$ Indonesian Rupiah 
Table 3. Multivariable Logistic Regression Predicting Social Distancing Practice $(\mathrm{n}=422)$

\begin{tabular}{lrrrrr}
\hline \multirow{2}{*}{ Variable } & \multicolumn{5}{c}{ Practice of Social Distancing } \\
\cline { 2 - 6 } & \multicolumn{1}{c}{$\boldsymbol{\beta}$} & SE & p-value & AOR & 95\% CI \\
\hline Age (18-21 years old ref) & 0.88 & 0.21 & $0.045^{*}$ & 1.47 & $1.97-2.22$ \\
Sex (Male ref) & 0.81 & 0.24 & $0.001^{*}$ & 2.26 & $1.38-3.69$ \\
Knowledge (Poor ref) & -0.05 & 0.21 & 0.806 & 0.94 & $0.62-1.44$ \\
Attitude (Negative ref) & 0.96 & 0.32 & $<0.001^{*}$ & 2.61 & $1.74-3.90$ \\
\hline
\end{tabular}

Notes: ${ }^{\mathrm{b}} \mathrm{AOR}=$ Adjusted Odds Ratio, $\mathrm{SE}=$ Standard Error, $\mathrm{CI}=$ Confidence Interval, *Significance level at $\mathrm{p}$-value $<0.05$,

\section{Discussion}

This study's findings showed that age, sex, and attitude were significant predictors of social distancing practice among undergraduate health students. According to the age, the results indicated that older health students tended to have good social distancing practice compared to younger ones. Similar to the previous studies, they reported that older individuals were more likely to pay attention than younger individuals. ${ }^{13,24}$ It also implied that older people tended not to expose themselves to certain risky social behaviors. In this study, sex was also associated with social distancing practice. Similar to a recent study in India, ${ }^{15}$ that examined how practice scores were affected by gender, a study in Indonesia, ${ }^{14}$ also explained that female students were more likely to comply with social distancing because women generally emphasize the notion of health-related to relaxation, rest, feeling well, and nutrition. Their naturally cautious natures shaped females to adopt healthy behaviors. Supporting these arguments, a study in China, ${ }^{24}$ revealed that males were more careless than females. Regarding that matter, this study only assessed five variables from general characteristics, suggesting that more general characteristic factors could be included in future studies.

This study revealed that those with positive attitudes were associated with good social distancing practice. This finding is consistent with the previous studies. ${ }^{12,14,25}$ This is linked to the behavioral model, which stated that attitude could drive behavior or form the intention to behave. ${ }^{26,27}$ The finding of this attitude predictor toward social distancing practice is possibly helpful for policymakers and healthcare professionals to further health interventions, raising awareness of health guidelines compliance. However, there was no significant association between knowledge and practice of social distancing. This study's results conflicted with other previous studies that found this variable was the protective factor of social distancing practice. ${ }^{3,12,14,24}$ Nevertheless, some studies reported no relationship between knowledge and preventive behavior. ${ }^{27,28}$ The possible reason was that adolescent health behaviors are highly determined by the living context. ${ }^{29}$ This implies that knowledge contains essential aspects for health behavior but is insufficient; supportive adolescent living contexts and school settings are also important. ${ }^{29,30}$ This study suggests that comprehensive prevention programs should be designed in living environments and academic settings.

Interestingly, this study found that social media was the main source of social distancing information used by participants. These findings were in line with three other studies from different settings. ${ }^{31-33}$ College students mainly were familiar with Facebook for information updates of the COVID-19.32,33 Science content in social media were perceived as share-worthy content that spreads quickly. Generation $\mathrm{Z}$ and Millennials are highly concerned about the COVID-19 infection among themselves and their family members. Therefore, they tended to follow newly updated information during uncertain periods closely. ${ }^{34}$ However, WHO keeps fighting the infodemic of COVID-19 mis- or disinformation widely proliferating online media sources. ${ }^{35}$ Local health authorities should actively design health promotions through this platform to eliminate hoaxes and myths about COVID-19 prevention measures. Social distancing promotion strategies involving health students may be more effective if considerations are given to specific high-risk populations, such as men in general and university students below 20 years old. Health campaigns through social media platforms should be an efficient way to educate social media users with accurate information by trustful authorities.

The limitation of this study was its questionable generalizability due to only one university in Samarinda City. Thus, further studies should involve more academic institutions from other universities or cities besides Samarinda to be more representative and reflect the situation throughout the entire country. The use of the online questionnaire platform can limit the ability of groups without internet access to respond to online questionnaires. The method of recruiting research subjects with probability sampling techniques should be considered to achieve the generalization and background diversity of samples. Further studies should be conducted to facilitate the comprehensive overview of health protocols that var- 
ious states and countries implemented to finally accelerate efforts to eradicate COVID-19.

\section{Conclusion}

In summary, general characteristics such as age, sex, and attitudes were the important predictors of the COVID-19 social distancing practice among undergraduate health students. The findings of this study imply that there is an urgent need to initiate a campaign comprehensively targeting specific high-risk populations along with health education programs in both residential and academic settings. This study found that social media was the most frequent information source about social distancing for students. Thus, a more tailored health education program could be efficiently run through this platform.

\section{Abbreviations}

WHO: World Health Organization; COVID-19: coronavirus disease 2019; ICTF: Indonesia COVID-19 Taskforce; IDR: Indonesian Rupiah; AOR: Adjusted Odds Ratio; SD: Standard Deviation; CI: Confidence Interval.

\section{Ethics Approval and Consent to Participate}

This study was conducted with ethical approval from the research ethics committee of the University of Mulawarman, Samarinda, Indonesia (No.25/KEPK-FK/III/2021) and the University of Muhammadiyah Jakarta, Indonesia (No.059/PE/KE/FKK-UMJ/II/2021).

\section{Competing Interest}

The authors declare that there are no significant competing financial, professional, or personal interests that might have affected the performance or presentation of the work described in this manuscript.

\section{Availability of Data and Materials}

The datasets used are available from the corresponding author on reasonable request.

\section{Authors' Contribution}

SHA performed the data collection and designed and drafted the initial manuscript. PV conceptualized the research, performed the statistical analysis, interpreted results, and finalized the manuscript.

\section{Acknowledgment}

The authors would like to acknowledge the participants involved for their valuable responses that contribute to this study.

\section{References}

1. World Health Organization. WHO Coronavirus (COVID-19) Dashboard: World Health Organization; 2021.

2. Dwivedi YK, Hughes DL, Coombs C, Constantiou I, Duan Y, Edwards JS, et al. Impact of COVID-19 pandemic on information management research and practice: transforming education, work and life; 2020.
3. Yanti B, Wahyudi E, Wahiduddin W, Novika R, Arina Y, Martani N, et al. Community knowledge, attitudes, and behavior towards social distancing policy as prevention transmission of Covid-19 in Indonesia. Jurnal Administrasi Kesehatan Indonesia. 2020; 8: 4.

4. World Health Organization. Coronavirus disease (COVID-19) advice for the public: World Health Organization; 2021.

5. Pedersen MJ, Favero N. Social distancing during the COVID-19 pandemic: who are the present and future noncompliers? Public Administration Review. 2020;80(5):805-14.

6. Ahmed F, Zviedrite N, Uzicanin A. Effectiveness of workplace social distancing measures in reducing influenza transmission: a systematic review. BMC Public Health. 2018; 18 (1): 1-13.

7. Chen S, Zhang Z, Yang J, Wang J, Zhai X, Bärnighausen T, et al. Fangcang shelter hospitals: a novel concept for responding to public health emergencies. The Lancet. 2020; 395 (10232): 1305-14.

8. Fong MW, Gao H, Wong JY, Xiao J, Shiu EY, Ryu S, et al. Nonpharmaceutical measures for pandemic influenza in nonhealthcare settings—social distancing measures. Emerging Infectious Diseases. 2020; 26 (5): 976.

9. World Health Organization. Coronavirus disease (COVID-19) pandemic: the math behind why we need social distancing; 2020.

10. Adisasmito W. Impact of COVID-19 pandemic on health. FKM UI Seminar Online Seri 38 Catatan Perjalanan Penanganan Covid-19 di Indonesia dan Asia; 2020.

11. Satuan Tugas Penanganan COVID-19. Pedoman pencegahan dan pengendalian coronavirus disease (COVID-19) guidelines for the prevention and control of coronavirus disease (COVID-19). In: Indonesia MoHR, editor. Indonesia: Ministry of Health Republic Indonesia. 2021 p.11-2.

12. Ferdous MZ, Islam MS, Sikder DM, Syed A, Zegarra A, Gozal D. Knowledge, attitude, and practice regarding COVID-19 outbreak in Bangladesh: an online-based cross-sectional study. PLoS ONE. 2020; $15: 0239254$.

13. Al-Hanawi, Mohammed $\mathrm{K}$ et al. Knowledge, attitude and practice toward COVID-19 among the public in the Kingdom of Saudi Arabia: a cross-sectional study. Frontiers in Public Health. 2020; 8 (217).

14. Syadidurrahmah F, Muntahaya F, Islamiyah SZ, Fitriani TA, Nisa H. Perilaku physical distancing mahasiswa UIN Syarif Hidayatullah Jakarta pada masa pandemi covid-19. Perilaku dan Promosi Kesehatan: Indonesian Journal of Health Promotion and Behavior. 2020; 2 (1): 29-37.

15. Maheshwari S, Gupta PK, Sinha R, Rawat P. Knowledge, attitude, and practice towards coronavirus disease 2019 (COVID-19) among medical students: a cross-sectional study. Journal of Acute Disease. 2020; 9 (3): 100.

16. Barrett C, Cheung KL. Knowledge, socio-cognitive perceptions and the practice of hand hygiene and social distancing during the COVID19 pandemic: a cross-sectional study of UK university students. BMC Public Health. 2021; 21 (1): 426.

17. Azlan AA, Hamzah MR, Sern TJ, Ayub SH, Mohamad E. Public knowledge, attitudes and practices towards COVID-19: a cross-sectional study in Malaysia. Plos One. 2020; 15 (5): e0233668.

18. Peltzer K, Pengpid S, Yung TK, Aounallah-Skhiri H, Rehman R. Comparison of health risk behavior, awareness, and health benefit be- 
liefs of health science and non-health science students: an international study. Nursing \& Health Sciences. 2016; 18 (2): 180-7.

19. Peng Y, Pei C, Zheng Y, Wang J, Zhang K, Zheng Z, Zhu P. A crosssectional survey of knowledge, attitude and practice associated with COVID-19 among undergraduate students in China. BMC Public Health. 2020 (1292): 1-8.

20. Baniyas N, Sheek-Hussein M, Al Kaabi N, Al Shamsi M, Al Neyadi M, Al Khoori R et al. COVID-19 knowledge, attitudes, and practices of United Arab Emirates medical and health sciences students: a cross sectional study. PLoS One, 2021; 16 (5): e0246226.

21. Dwivedi YK, Hughes DL, Coombs C, Constantiou I, Duan Y, Edwards IS, et al. Impact of COVID-19 pandemic on information management research and practice: transforming education, work and life. International Journal of Information Management. 2020; 55: 102211.

22. Saefi M, Fauzi A, Kristiana E, Adi WC, Muchson M, Setiawan ME, et al. Survey data of COVID-19-related knowledge, attitude, and practices among indonesian undergraduate students. Data in brief. 2020; 31: 105855.

23. Selby K, Durand M-A, Gouveia A, Bosisio F, Barazzetti G, Hostettler $\mathrm{M}$, et al. Citizen responses to government restrictions in Switzerland during the COVID-19 pandemic: cross-sectional survey. JMIR Formative Research. 2020; 4 (12): e20871.

24. Zhong B-L, Luo W, Li H-M, Zhang Q-Q, Liu X-G, Li W-T, et al. Knowledge, attitudes, and practices towards COVID-19 among Chinese residents during the rapid rise period of the COVID-19 outbreak: a quick online cross-sectional survey. International Journal of Biological Sciences. 2020; 16 (10): 1745.

25. Alahdal H, Basingab F, Alotaibi R. An analytical study on the awareness, attitude and practice during the COVID-19 pandemic in Riyadh, Saudi Arabia. Journal of infection and Public Health. 2020; 13 (10): 1446-52.
26. Robbins SP, Judge TA. Perilaku organisasi (Organizational behavior 16th edition). Jakarta: McGraw Hill dan Salemba Empat; 2015.

27. Rakotoarisoa FM, Praptapa A, Suyono E, Usuman I. Factors influencing preventive intention behavior towards covid-19 in Indonesia. The Journal of Behavioral Science. 2021; 16 (1): 14-27.

28. Azfar M, Omarulharis S, Azfar H, Maryam A, Hafizah S, Adibah B, et al. Knowledge, attitude and practice of dengue prevention among sub urban community in Sepang, Selangor. International Journal of Public Health and Clinical Sciences. 2017; 4 (2): 73-83.

29. Nagy-Pénzes G, Vincze F, Sándor J, Bíró É. Does better health-related knowledge predict favorable health behavior in adolescents? International Journal of Environmental Research and Public Health. 2020; 17 (5): 1680

30. Arlinghaus KR, Johnston CA. Advocating for behavior change with education. American Journal of Lifestyle Medicine. 2018; 12 (2): 113-6.

31. Bhagavathula AS, Aldhaleei WA, Rahmani J, Mahabadi MA, Bandari DK. Knowledge and perceptions of COVID-19 among health care workers: cross-sectional study. JMIR Public Health \& Surveillance. 2020; 6 (2): e19160.

32. Hajar HW, Rachman MA. Peran media sosial pada perilaku informasi mahasiswa dalam menyikapi isu kesehatan. Jurnal Ilmu Informasi, Perpustakaan, dan Kearsipan. 2020; 22(2).

33. Radwan E, Radwan A, Radwan W. The role of social media in spreading panic among primary and secondary school students during the COVID-19 pandemic: an online questionnaire study from the Gaza Strip, Palestine. Heliyon. 2020; 6 (12): e05807.

34. World Health Organization. Social media \& covid-19: a global study of digital crisis interaction among gen $\mathrm{z}$ and millenials. World Health Organization; 2020.

35. Chen W, Wang Q, Li YQ, Yu HL, Xia YY, Zhang ML, et al. Early containment strategies and core measures for prevention and control of novel coronavirus pneumonia in China. Zhonghua Yu Fang Yi Xue Za Zhi. 2020; 54 (3): 239-44. 